\title{
Skin Health Improving Effects of Korean Freeze-dried Royal Jelly in Human Keratinocytes
}

Hyo Young Kim, Hong Min Choi, Se Gun Kim, Soon Ok Woo, Hyo Jung Moon, Sang Mi Han*

Department of Agricultural Biology, National Institute of Agricultural Sciences, Wanju-gun, Jeollabuk-do, Korea

\author{
*Corresponding author: Sang-mi Han, \\ Sericulture and Apiculture Division, \\ Department of Agriculture Biology, National \\ Institute of Agricultural Sciences, 166, \\ Nongsaengmyeong-ro, Iseo-myun, Wanju- \\ gun, Jeollabuk-do, Republic of Korea \\ Tel.: +82632382896 \\ Fax: +82632382834 \\ Email: sangmih@korea.kr
}

Received July 24, 2020

Revised August 14, 2020

Accepted September 01, 2020

Published September 30, 2020

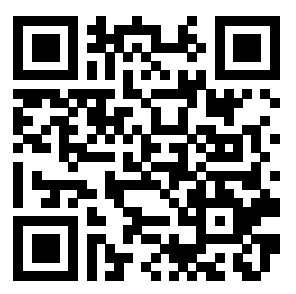

\begin{abstract}
Purpose: In this study, we aimed to examine the anti-skin aging effects of Korean freeze-dried royal jelly and its main ingredient, 10-Hydroxydecanoic acid (10-HDA), in order to promote Korean royal jelly as a health functional food ingredient for improving skin health. Methods: The effects of Korean freeze-dried royal jelly and 10-HDA were determined by examining the proliferation and migration of human keratinocytes (HaCaT cells) in a skin wound healing model by using EZ-cytox kit assay. The changes in production of matrix metalloproteinase (MMP)-1 and MMP-3, which are related to skin aging in HaCaT cells, after UV-B irradiation were analyzed using enzyme-linked immunosorbent assay. Real-time polymerase chain reaction was employed to analyze MMP-1 and MMP-3 gene expression. Results: Korean freeze-dried royal jelly and 10-HDA improved the regeneration and migration of mechanically damaged HaCaT cells. The test group treated with $100 \mu \mathrm{g} / \mathrm{mL}$ of Korean freeze-dried royal jelly and $100 \mu \mathrm{M}$ of 10 -HDA yielded similar results to those obtained for the positive control group treated with vitamin C. Furthermore, Korean freeze-dried royal jelly and 10-HDA significantly reduced the production and gene expression of MMP-1 and MMP-3, which are the key elements that induce skin aging by suppressing collagen generation in UVB-irradiated HaCaT cells. Conclusion: We examined the anti-wrinkle effects of Korean freeze-dried royal jelly and its main ingredient, 10-HDA. The results suggested the applicability of Korean royal jelly as a key functional health food ingredient for improving skin health.
\end{abstract}

Keywords: Royal jelly, 10-Hydroxydecanoic acid, Health functional food, Human keratinocyte, Anti-wrinkle

\section{Introduction}

피부는 신체의 외부 표면을 둘러싸고 있는 가장 큰 기관으로 외 부 환경으로부터 신체 내부를 보호하는 장벽으로 체온조절, 수분 손실과 미생물에 대한 감염으로부터 신체를 보호하는 다양한 기능 을 가지고 있다(Rittié \& Fisher, 2002; Zhang \& Duan, 2018). 구조적으로 피부는 표피(epidermis), 진피(dermis) 그리고 피하지 방(subcutaneous fat)으로 구성되어 있으며 표피를 구성하는 세포 는 각질형성세포(keratinocyte)로 이루어져 있으며 그 외에 멜라닌 세포(melanocyte), 랑게르한스세포(langerhan cell) 및 머켈세포 (merkel cell)로 이루어져 있다. 피부의 노화는 크게 내인성 노화와 외인성 노화(광노화)로 나눌 수 있으며 내인성 노화의 임상적 특징 은 비교적 경미하며, 잔주름, 피부건조증, 탄력감소 등을 들 수 있
다(KFDA 2019a). 그러나 자외선과 같이 외부 환경에 의한 외인 성 피부노화는 내인성 노화에 비하여 굵고 깊은 주름과 잔주름이 발생하며, 심한 경우 피부건조증, 탄력감소, 색소성 질환, 양성종 양, 피부암 등을 증가시킨다(KFDA, 2019a). 특히 자외선 B (UVB, 290-320 nm)는 matrix maetalloproteinase (MMPs)의 생성을 유도하고, 피부각질세포 내 DNA 손상과 조직의 산화적 스트레스 를 유발하는 광노화의 주요 원인이다(Ma et al., 2003; Kalbina \& Strid, 2006; Ryu et al., 2019). 노화된 피부에서 가장 대표적으 로 나타나는 변화는 콜라겐(collagen) 섬유의 양적 구조적 변화이 다(Fisher et al., 1997; Quan \& Fisher, 2015). 콜라겐 분해의 증 가와 생합성 감소가 동시에 일어나게 되면 콜라겐의 항상성에 이상 이 야기되고 결국 콜라겐의 감소가 유발되고 이러한 변화는 피부 주름과 탄력 감소를 초래한다고 한다(Varani et al., 2000). Matrix 
metalloproteinase (MMPs) 효소는 세포외기질(extracellular matrix) 단백질을 분해할 수 있는 기능을 가지며 특히 MMP- 1 은 collagenase 1으로 알려져 있으며, type I 와 III collagen을 기질 로 한다. MMP- 3 는 stromelysin 1 이라고도 하며, 기저막의 type collagen을 분해하며 zymogen인 proMMP-1을 활성화시킨다 (Brennan et al., 2003; KFDA, 2019a; Lee \& Park, 2019).

로열젤리(royal jelly)는 5-15일령의 어린 일벌이 꽃가루와 꿀 을 먹고 머리에 있는 인두선(hypopharyngeal gland)에서 분비하 는 양봉산물로 유충과 여왕벌의 먹이로 사용되는데 여왕벌에는 전 유충 기간과 성장 후에도 급여되고, 일벌과 수벌의 유충은 부화 후 3 일간만 급여된다. 로열젤리는 유백색의 점액상 물질로 산성이며, 다소 자극성 냄새를 갖고 있으며, 수분, 단백질, 지방, 탄수화물, 비 타민, 무기물 이외에 생리활성물질로 이루어진 복합물질이다. 로열 젤리의 주요성분은 10-hydroxydecanoic acid (10-HDA)와 major royal jelly protein (MRJP)로 알려져 있으며 우리나라에서는 10$\mathrm{HDA}$ 를 로열젤리의 규격으로 설정되어 있다(KFDA, 2019b). 오래 전부터 전 세계적으로 로열젤리는 자양강장제와 같은 건강기능식 품으로 널리 사용되고 있으며, 항종양, 면역강화, 항염증, 항고혈 압, 항노화 및 콜라겐 생성과 피부보습 등의 약리적 효능이 알려져 있다. 특히 아시아 지역에서는 화장품, 건강 보조제 및 음료 등의 시장으로 크게 확대되고 있으며, 국산 로열젤리가 피부 멜라닌세포 의 세포 내 티로시나아제(tyrosinase) mRNA 전사를 억제함으로써 티로시나아제 활성과 멜라닌 합성을 감소시키는 것으로 확인하고, 피부 관련 기능성 소재로서 활용가치가 높은 것으로 보고한 바 있 다(Han et al., 2011). 국내는 물론 해외에서도 로열젤리에 대한 피 부재생, 피부미백 및 보습 등 탁월한 효능이 보고되어 있으나, 아직 까지 국내에서는 건강기능식품원료로 인정되어 있지 않아 고부가 가치 소재로의 활용에 제약을 받고 있다.

따라서 본 연구는 국내 양봉농가에서 생산한 동결건조 로열젤리 의 영양성분 및 10-HDA 함량을 분석하고 자외선과 피부 상처에 의한 피부손상으로부터 피부건강 유지에 도움을 주는 건강 기능식 품 원료로서의 가능성을 평가하고자 하였다.

\section{Materials and Methods}

\section{1. 공시시료}

시험에 사용한 로열젤리는 한국양봉협회 (Korea)로부터 2019 년에 채취한 생 로열젤리를 구입 후 동결건조하여 사용하였 다. 동결건조 한 로열젤리의 10-HDA 함량 분석은 Ultra high performance liquid chromatography (UPLC; Waters, USA)을 사용하였다(Kim et al., 2014). 동결건조한 로열젤리의 수분, 단백 질 등은 분석하였다. 동결건조 로열젤리를 용량플라스크에 넣은 후 메탄올을 사용하여 $5 \mathrm{mg} / \mathrm{mL}$ 의 농도가 되도록 만들고 $40^{\circ} \mathrm{C}$ 에서
$30 \mathrm{~min}$ 간 초음파 추출기를 사용하여 추출한 후 $0.2 \mu \mathrm{m}$ 필터를 사 용하여 여과하였다. 표준품 10-HAD (Nacalai tesque, Japan) 역시 로열젤리와 동일한 방법으로 전처리 하였다.

\section{2. 동결건조 로열젤리의 성분 분석}

생로열젤리와 동결건조 로열젤리의 수분 분석은 식품공전의 일반 시험법 식품성분시험법에 따라 상압가열건조법을 사용하여 분석하 였다. 조단백질과 조지방, 회분 역시 식품공전 일반시험법 식품성분 시험법으로 분석하였다(KFDA, 2019c). 10-HDA 분석은 식품공전 로열젤리가공식품 10- $\mathrm{HDA}$ 분석법에 따라 고속액체크로마토그래 피(HPLC; Agilent, USA)를 이용하여 정량분석 하였으며 $10-\mathrm{HDA}$ 를 표준품으로 사용하였다(KFDA, 2019c). 비타민 조성은 건강식품 공전의 비타민 시험법에 따라 시료의 전처리 및 함량 분석을 실시하 였다. 무기질 중 나트륨 $(\mathrm{Na})$, 마그네슘 $(\mathrm{Mg})$, 칼륨 $(\mathrm{K})$, 칼슘 $(\mathrm{Ca})$, 망 간 $(\mathrm{Mn})$, 철 $(\mathrm{Fe})$, 구리 $(\mathrm{Cu})$, 아연 $(\mathrm{Zn})$, 인(P)은 식품공전의 일반시험 법과 건강기능식품공전의 건강기능식품 시험법에 제시된 건식분해 법에 따라 검체를 건조하여 탄화시키고 $450-550^{\circ} \mathrm{C}$ 에서 완전히 회 화시킨 후 염산을 추가하여 유리여과기로 여과한 다음 유도 결합 플 라즈마 발광분석기 (ICAP 7400 Duo; Thermo Fisher Scientific, $\mathrm{USA}$ 를 이용하여 함량을 측정하였다. 몰리브덴(Mo) 및 셀레늄(Se) 역시 건식분해법에 의하여 시료를 전처리하고 함량 분석은 Agilent ICP-MS 7700 (Santa Clara, USA)을 사용하였다. 염소(Cl) 분석은 식염 $1 \mathrm{~g}$ 을 함유하는 양의 검체를 회화시킨 후 물에 녹이고 여과하여 크롬산 칼륨시액을 첨가한 다음 질산은 용액으로 적정하여 염소의 양을 산출하였다.

\section{3. 세포배양}

본 연구에서 사용된 각질형성세포(HaCaT cell)는 한국세포주은 행(Korea)으로 구입하여 사용하였다. $\mathrm{HaCaT}$ 세포는 Dulbecco's modified eagle medium (DMEM; Thermo Fisher Scientific) 배 지에 10\% fetal bovine serum (FBS; Thermo Fisher Scientific, USA)와 1\% penicillin/strptomycine (penicillin $100 \mathrm{IU} / \mathrm{mL}$, streptomycin $100 \mu \mathrm{g} / \mathrm{mL}$; Thermo Fisher Scientific)를 첨가하여 $37^{\circ} \mathrm{C}, 5 \% \mathrm{CO}_{2}$ 조건의 배양기에서 배양하였다.

\section{4. 세포 생존율 측정}

동결건조 로열젤리와 $10-\mathrm{HDA}$ 대한 $\mathrm{HaCaT}$ 세포 생존율 및 증 식 효능은 EZ-Cytox cell viability assay kit (Dogen, Korea)를 사 용하여 측정하였다. $\mathrm{HaCaT}$ 세포를 96 well plate에 최종 농도가 $2 \times$ $10^{5} \mathrm{cells} / \mathrm{mL}$ 가 되도록 분주한 뒤 $37^{\circ} \mathrm{C}, 5 \% \mathrm{CO}_{2}$ incubator에서 24 $\mathrm{h}$ 배양하였다. 배양 된 세포에 동결건조 로열젤리와 10- $\mathrm{HDA}$ 를 각 각 다양한 농도별로 처리하고 $24 \mathrm{~h}$ 배양 후 EZ-Cytox 시약 $10 \mu \mathrm{L}$ 를 처리한 다음 $4 \mathrm{~h}$ 동안 배양 후 microplate reader (BioSurplus; Spectramax M2, USA)를 이용하여 $480 \mathrm{~nm}$ 에서 흡광도를 측정하 
였다. 세포 재생 효능은 대조군에 대한 생존율로 나타내었다.

\section{5. 세포 이주 및 재생 효능 평가}

피부 상처 세포 모델(wound healing assay)은 HaCaT세포를 6 well plate에 최종 농도가 $2 \times 10^{5} \mathrm{cells} / \mathrm{mL}$ 가 되도록 분주한 뒤 $37^{\circ} \mathrm{C}, 5 \% \mathrm{CO}_{2}$ 배양기에서 세포가 $90 \%$ 이상 증식한 상태가 될 때까 지 배양하였다(Kim et al., 2019). 충분히 세포가 안정화 되었을 때 멸균한 $200 \mu \mathrm{L}$ pipette tip (Thermo Fisher, USA)으로 배양 접시 를 긁어 상처를 유도하였다. 동결건조 로열젤리와 10- $\mathrm{HDA}$ 를 농도 별로 처리 한 후 시간대별로 세포의 이동 정도를 현미경 (EVOS XL core; Thermo Fisher, USA)을 이용하여 관찰하였다. 또한 재생 효 능은 EZ-Cytox cell viability assay kit를 사용하여 측정하였다.

\section{Matrix metalloproteinase (MMP)-1과 MMP-3 발현량 측정}

$\mathrm{HaCaT}$ 세포는 6 well plate에 $3 \times 10^{4}$ cells $/ \mathrm{mL}$ 로 분주한 다음 $37^{\circ} \mathrm{C}, 5 \% \mathrm{CO}_{2}$ 배양기에서 $24 \mathrm{~h}$ 배양 후 $\mathrm{PBS}$ 로 세척한 다음 $\mathrm{UVB}$ lamp (LF-215.LM; UVITEC Cambridge, UK)를 이용하여 $4 \mathrm{~mW} /$ $\mathrm{cm}^{2}$ 조사량을 $10 \mathrm{~s}$ 노출시켜 $40 \mathrm{~mJ} / \mathrm{cm}^{2}$ 으로 조사하였다(Ryu et al., 2019). 양성대조군인 vitamin C, 동결건조 로열젤리와 10$\mathrm{HDA}$ 를 농도별 처리하고 $24 \mathrm{~h}$ 동안 배양하였다. 배양 후 $\mathrm{MMP}-$ 1,3 의 발현은 human MMP-1 ELISA kit (Abcam, UK)와 human MMP-3 ELISA kit (Abcam)를 사용하여 프로토콜에 따라 측정 하였다. MMP-1 또는 MMP-3 항체가 코팅 된 plate에 배양액 및 antibody cocktail을 각각 $50 \mu \mathrm{L} /$ well씩 분주한 후 $1 \mathrm{~h}$ 동안 실온에 서 반응하였다. 세척작업 3회 후 TMB solution $100 \mu \mathrm{L} / \mathrm{well}$ 를 첨가 하여 암 조건에서 $10 \mathrm{~min}$ 간 발색 반응한 후 stop solution $100 \mu \mathrm{L} /$ well를 처리하여 $450 \mathrm{~nm}$ 에서 흡광도를 측정하였다.
$\mathrm{HaCaT}$ 세포를 6 well plate에 $3 \times 10^{4}$ cells $/ \mathrm{mL}$ 농도로 $24 \mathrm{~h}$ 배 양한 후 PBS로 세척한 다음 UVB lamp를 이용하여 $40 \mathrm{~mJ} / \mathrm{cm}^{2}$ 으 로 조사하였다. 양성대조군인 vitamin $\mathrm{C}$, 동결건조 로열젤리와 10$\mathrm{HDA}$ 를 농도별 처리하고 $24 \mathrm{~h}$ 동안 배양하였다. Total RNA 분리 는 RNeasy mini kit (Qiagen, Germany)를 이용하였고 제조사의 권장 방법에 따라 사용하였다. 먼저 상층액을 제거하고 $\mathrm{PBS}$ 로 1 회 washing 후 RLT buffer를 가하여 세포를 용해한 뒤 $70 \%$ 에탄 올을 첨가하여 total RNA를 추출하였다. $\mathrm{cDNA}$ 합성은 PrimeScript II 1st strand cDNA synthesis kit (Takara, Japan)를 이용하여 진 행하였다. PCR tube에 total RNA $6 \mu \mathrm{L}$ 와 random hexamer $1 \mu \mathrm{L}$, $\mathrm{dNTP}$ mixture $1 \mu \mathrm{L}$, RNase free water $2 \mu \mathrm{L}$ 를 첨가하여 $65^{\circ} \mathrm{C} 5$ $\min , 4^{\circ} \mathrm{C}$ 에서 $5 \mathrm{~min}$ 반응시켰다. 이후 반응물에 $5 \mathrm{X}$ buffer $4 \mu \mathrm{L}$, primescript RTase $1 \mu \mathrm{L}$, RNase inhibitor $0.5 \mu \mathrm{L}$, RNase free water $4.5 \mu \mathrm{L}$ 를 혼합하여 $30^{\circ} \mathrm{C} 10 \mathrm{~min}, 42^{\circ} \mathrm{C} 1 \mathrm{~h}, 95^{\circ} \mathrm{C} 5 \mathrm{~min}$ 반 응을 통하여 $\mathrm{cDNA}$ 를 합성하였다. 타깃 $\mathrm{mRNA}$ 발현을 평가하기 위 하여 real-time PCR은 SYBR Premix Ex Taq (Takara, Japan)를 이용한 후 CFX96 touch real-time PCR detection system (Bio$\mathrm{rad}, \mathrm{USA}$ )에서 수행하였다. $\mathrm{PCR}$ 증폭은 $95^{\circ} \mathrm{C}$ 에서 $10 \mathrm{~min}$ 동안 예 비 가열 후 denaturation은 $94^{\circ} \mathrm{C}$ 에서 $20 \mathrm{~s}$, annealing은 각 specific primer sequences에 맞는 온도에서 $20 \mathrm{~s}$, extension은 $72^{\circ} \mathrm{C}$ 에서 30 $\mathrm{s}$ 의 조건으로 40 회 반복하였으며, $72^{\circ} \mathrm{C}$ 에서 $10 \mathrm{~min}$ 동안 안정화 과 정을 진행하였다. 각각의 specific primer sequence는 Table 1 과 같 다.

\section{8. 자료분석}

$\mathrm{R}$ 통계프로그램 (R project, Australia)을 이용하여 각 군간의 비 교 분석을 위하여 Duncan's multiple range test를 실시하여 검정하 였고 $p<0.05$ 인 경우 통계적으로 유의한 것으로 판정하였다.

\section{Total RNA 분리 및 real-time PCR}

Table 1. Primer sequence for the amplification of target genes

\begin{tabular}{|c|c|c|c|}
\hline Gene & Primer sequence $\left(5^{\prime} \rightarrow 3^{\prime}\right)$ & Amplification size (bp) & Annealing temperature $\left({ }^{\circ} \mathrm{C}\right)$ \\
\hline$M M P-1$ & $\begin{array}{l}\text { F:GATGTGGAGTGCCTGATGTG } \\
\text { R:TGCTTGACCCTCAGAGACCT }\end{array}$ & 200 & 59.9 \\
\hline$M M P-3$ & $\begin{array}{l}\text { F:CACTCACAGACCTGACTCGGTT } \\
\text { R:AAGCAGGATCACAGTTGGCTGG }\end{array}$ & 156 & 63.9 \\
\hline GAPDH & $\begin{array}{l}\text { F:ACCACAGTCCATGCCATCAC } \\
\text { R:TCTAGACGGCAGGTCAGGTC }\end{array}$ & 224 & 61.9 \\
\hline
\end{tabular}

$M M P-1$, matrix metalloproteinase-1; MMP-3, matrix metalloproteinase-1; GAPDH, glyceraldehyde 3 phosphate dehydrogenase.

Table 2. Nutritional components and 10-HDA analysis of freeze-dried royal jelly

\begin{tabular}{|c|c|c|c|c|c|c|}
\hline \multirow{2}{*}{ Group } & \multicolumn{6}{|c|}{ Determinations (\%) } \\
\hline & Moisture & Proteins & Carbohydrate & Lipids & Ash & 10-HDA \\
\hline Freeze-dried royal jelly ${ }^{*}$ & $4.4 \pm 0.12$ & $38.8 \pm 3.60$ & $37.40 \pm 5.52$ & $7.00 \pm 1.74$ & $2.60 \pm 0.05$ & $6.20 \pm 0.69$ \\
\hline Food labelling standards ${ }^{* *}$ & $5 \leq$ & $30-41$ & - & - & - & $4 \geq$ \\
\hline
\end{tabular}

${ }^{*}$ Data are means \pm S.D. of 10 experiments. ${ }^{* *}$ Ministry of Food and Drug Safety. 


\section{Results and Discussion}

양봉농가에서 생산한 생(生)로열젤리는 수분 함량이 $60 \%$ 이상이 며 주 성분인 단백질 함량이 $11 \%$ 이상으로 냉장 및 상온에서 쉽게 변질될 우려가 있어 산업화에 걸림돌이 되었다. 본 연구에서는 다양 한 산업화 원료로 활용하기 위하여 이러한 단점을 보완한 동결건조 로열젤리를 사용하여 자외선에 의한 피부 노화 억제, 피부 상처에 의 한 피부세포 재생 및 이주 효능을 평가하고 로열젤리의 생리활성이 주요 성분으로 알려진 10-HDA에서 기인하는지를 알아보고자 하였 다.

\section{1. 국산 동결건조 로열젤리의 성분 분석}

시험에 사용한 동결건조 로열젤리는 국내 양봉농가에서 생산한 로 열젤리를 동결건조하여 시험에 사용하였다. 동결건조 로열젤리의 주 요 영양성분 및 10-HDA 함량은 Table 2와 같다. 시험에 사용한 국 산 동결건조 로열젤리는 우리나라 식품공전의 동결건조 로열젤리 제 품의 규격 기준인 수분 함량 $5 \%$ 이하, 단백질 함량은 30 에서 $41 \%$ 그 리고 10- $\mathrm{HDA}$ 함량 $4 \%$ 이상 조건을 모두 충족하였으며 10- $\mathrm{HDA}$ 함 량은 기준규격보다 $30 \%$ 이상 함량이 높았다(KFDA, 2019b), 로열젤

A

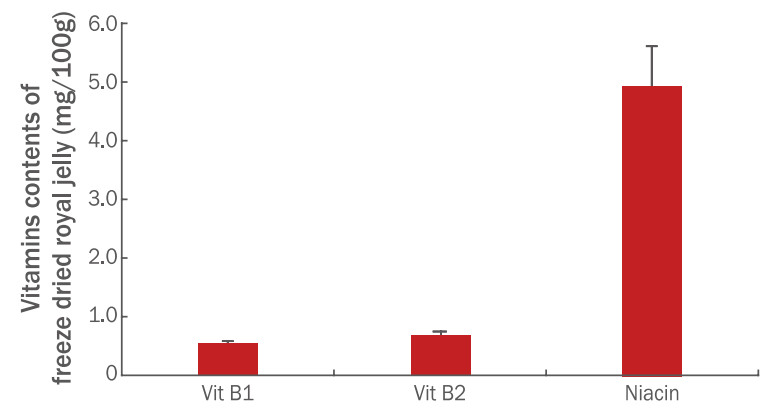

B

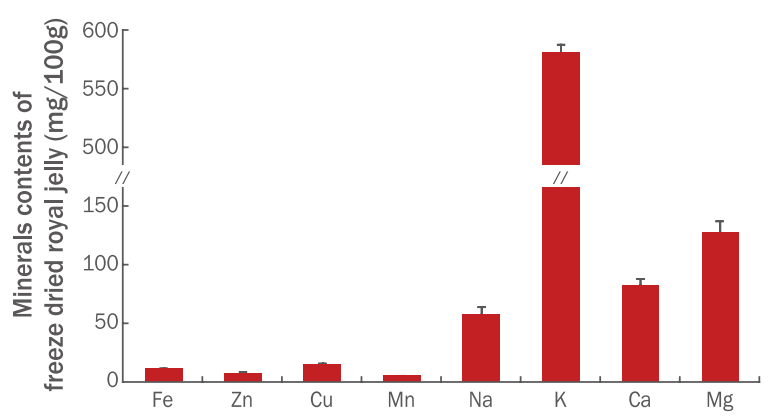

Figure 1. Vitamins and minerals contents in Korean freeze-dried royal jelly.

(A) Vitamins contents. (B) Mineral elements contents. Data are reported as mean \pm SD.
리는 비타민B1, B2 그리고 Niacine (B6)이 확인되었으며 niacin 함 량이 매우 높았다(Figure 1A). 또한 무기물 성분도 풍부했으며, 특히 칼륨과 마그네슘, 칼슘 함량이 높은 것으로 확인되었다(Figure 1B). 국산 동결건조 로열젤리는 높은 $10-\mathrm{HDA}$, 단백질 그리고 비타민과 무기물 성분으로 기존의 생로열젤리의 저장 및 이용에 있어 단점을 보완할 수 있어 다양한 식품 소재로 활용 가능성이 높아졌다.

\section{2. 국산 동결건조 로열젤리와 10-HDA의 피부 세포 독성 평가}

피부 각질형성세포는 피부 재생과 상처치유 등 피부조직의 재형 성 과정에서 매우 중요한 역할을 한다고 알려져 있다(Choung et al., 2013). 피부 각질형세포인 $\mathrm{HaCaT}$ 세포주는 화학적 또는 물리적 자 극에 의한 손상을 받게 되면 다양한 케모카인(chemokine)과 사이토 카인이 발현됨과 동시에 피부 손상 부위로 이동하여 피부 세포의 증 식을 유도한다고 알려져 있다(Choung et al., 2013). 10-HDA는 로 열젤리의 주요 지표 물질로 항암, 항균, 항염증 등 다양한 분야에 생 리활성효과를 나타내는 것으로 보고되어 왔으며(Fujiwara et al., 1990; Nagai \& Inoue, 2004; Han et al., 2011) 피부세포 증식 및 상처 치유에 효과가 있는 것으로 알려져 있다(Lin et al., 2019). 본

A

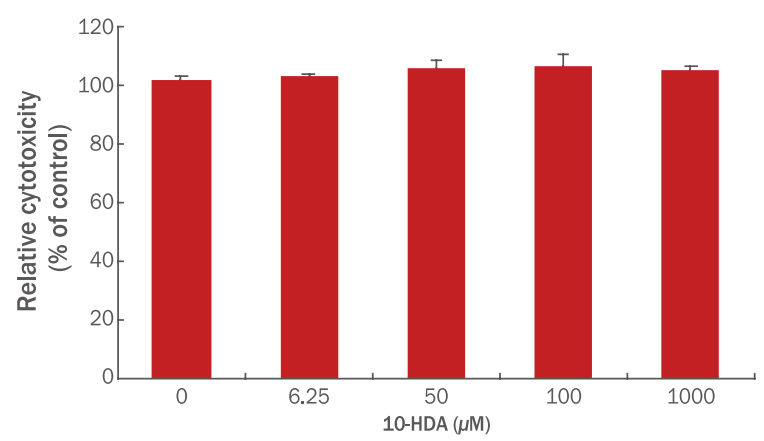

B

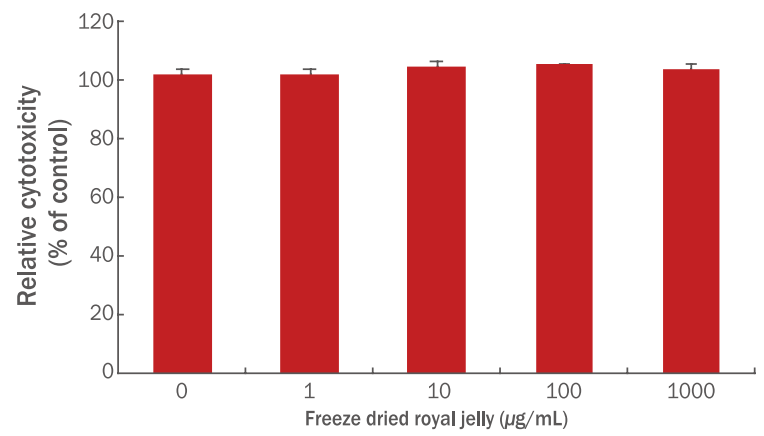

Figure 2. The cell viability analysis of the 10-HDA and freezedried royal jelly on the HaCaT cells.

Cell viability was measured using EZ-cytox kit assay. Cells were treated with (A) 10-HDA and (B) Freeze-dried royal jelly for $24 \mathrm{hr}$. Data are reported as mean \pm SD. 


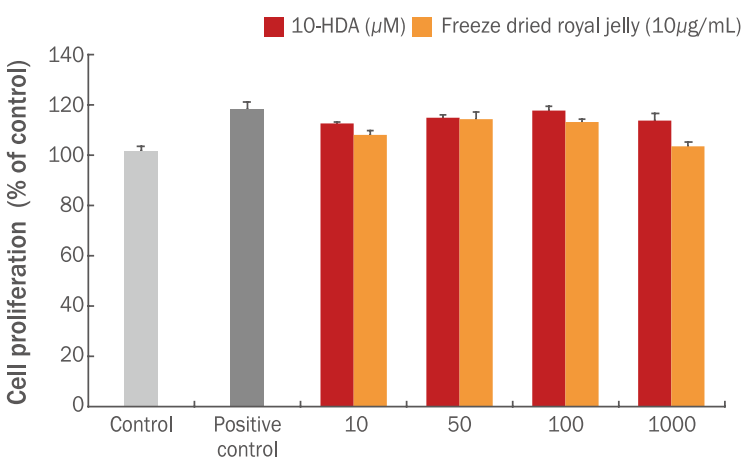

Figure 3. The effect of 10-HDA and freeze-dried royal jelly on the proliferation of HaCaT cells.

The wound healing assay determined the proliferation of HaCaT cells. Wound was scratched at $100 \%$ confluence, and cells were treated with the indicated concentration of 10-HDA $(\mu \mathrm{M})$ and freeze-dried royal jelly $(\mu \mathrm{g} / \mathrm{mL})$ for $48 \mathrm{~h}$. Vitamin $\mathrm{C}$ served as a positive control. Cell proliferation was measured using a EZ-cytox kit assay. Data are reported as mean \pm SD.

연구에서는 국산 동결건조 로열젤리의 피부 항노화 기능성 화장품 소재로 개발하고자 $\mathrm{HaCaT}$ 세포를 활용하여 $10-\mathrm{HDA}$ 의 피부세포 의 성장 및 이주능을 평가하고자 하였다. 동결건조 로열젤리 및 10$\mathrm{HDA}$ 의 $\mathrm{HaCaT}$ 세포에 대한 독성을 보이지 않는 실험 최대 농도를 설 정하기 위하여 세포독성을 평가하였다. Figure 2에서 보는 바와 같 이 동결건조 로열젤리는 $100 \mu \mathrm{g} / \mathrm{mL}$ 이상에서도 세포 독성을 유발 하지는 않았으나 $100 \mu \mathrm{g} / \mathrm{mL}$ 이상의 농도로 처리했을 경우엔 동결 건조 로열젤리가 충분히 용해 되지 않아 배지가 혼탁해지는 것을 확 인할 수 있었다. $10-\mathrm{HDA}$ 역시 $1,000 \mu \mathrm{M}$ 이상에서도 세포 독성은 유발하지 않았으나 배지가 혼탁해지는 것을 알 수 있었다. 이러한 연 구결과를 바탕으로 배지에 충분히 용해 될 수 있는 실험 최대 농도로 동결건조 로열젤리는 $100 \mu \mathrm{g} / \mathrm{mL}, 10-\mathrm{HDA}$ 는 $1,000 \mu \mathrm{M}$ 이내로 설 정하고 이 범위 내에서 피부세포의 재생 효과를 검증하고자 피부세 포상처 모델(wound healing assay)을 이용하여 동결건조 로열젤리 와 10-HDA의 피부세포 재생 및 이주능을 평가하였다.

\section{3. 국산 동결건조 로열젤리와 10-HDA의 피부 세포 증식 효과}

Figure 3 과 같이 동결건조 로열젤리는 $100 \mu \mathrm{g} / \mathrm{mL}$ 의 농도에서 피부세포 재생율이 가장 높았으며, $10-\mathrm{HDA}$ 에서는 $100 \mu \mathrm{M}$ 로 처리 한 시험구에서 세포 재생율이 가장 높았다. Figure 4 와 같이 HaCaT 세포에 동결건조 로열젤리와 10-HDA를 각각 농도별로 처리했을 때 농도 및 시간 의존적으로 무 처리구에 비하여 세포 성장 및 세포 이동이 증가하는 것으로 확인되었다. 동결건조 로열젤리 $100 \mu \mathrm{g} /$ $\mathrm{mL}$ 의 농도와 $10-\mathrm{HDA} 100 \mu \mathrm{M}$ 농도에서 $48 \mathrm{~h}$ 후 $\mathrm{HaCaT}$ 세포의 성장 및 이동한 면적은 양성 대조군으로 사용한 vitamin $\mathrm{C}$ 와 같은 효과를 나타내었다. 따라서 이러한 결과를 통해 국산 동결건조 로열

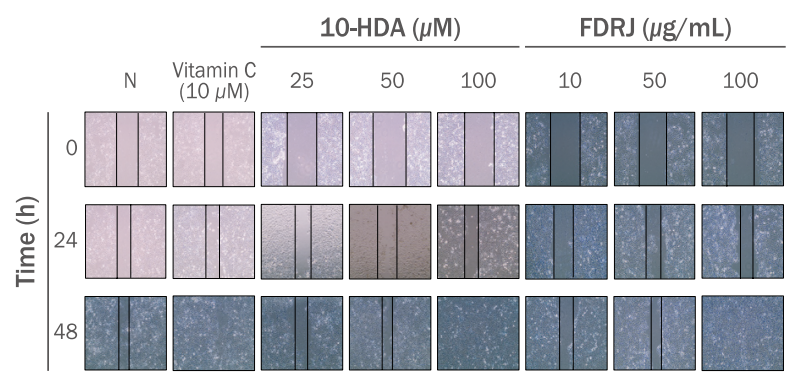

Figure 4. Cell regeneration effect of 10-HDA and freeze-dried royal jelly in HaCaT cells.

The wound healing assay was determined the migration of HaCaT cells. Wound was scratched at 100 confluence and cells were treated with the indicated concentrations of 10-HDA and freezedried royal jelly for $48 \mathrm{~h}$. Images were obtained at 0,24 , and $48 \mathrm{~h}$. Vitamin $\mathrm{C}$ was positive control. FDRJ, freeze-dried royal jelly.

젤리 및 지표 성분인 10-HDA의 피부세포 성장과 이주를 촉진함으 로써 피부세포의 증식을 유도하는 것으로 확인되었다.

\section{4. 국산 동결건조 로열젤리와 $10-\mathrm{HDA}$ 의 MMP-1 및 MMP-3 발 현 억제 효과}

노화와 자외선 등으로 인한 피부 노출은 MAPK (mitogenactivated protein kinase)를 활성화시킨다(KFDA, 2019a). MAPK 에서 가장 많이 영향을 받는 인자는 $\mathrm{AP}-1$ 이다. AP-1은 Jun 과 Fos family 단백질로 이루어진 전사인자로 c-Jun과 c-Fos의 heterodimer 형태로 존재 할 때 전사활성이 가장 높다. 사람의 피부 가 자외선에 노출되지 않았을 때는 c-FoS와 JunD의 이합체로 존재 하나, 자외선, 외부 환경적 자극 등에 의하여 c-Jun과 c-Fos 단백 질의 발현이 증가하게 되고, $\mathrm{c}-\mathrm{Jun}$ 은 JNK와 $\mathrm{p} 38$ 에 의한 인산화에 의하여 활성화된다(KFDA, 2019a). $\mathrm{AP}-1$ 은 세포와 분화에 관련되 는 많은 유전자의 발현을 조절하고 몇몇 $\mathrm{MMPs}$ 의 발현을 강력히 조 절한다(Scharffetter-Kochanek et al., 2000). MMPs는 zinc이온 을 요하는 endoprotease로 세포외기질 단백질을 분해하는 효소이다. $\mathrm{AP}-1$ 에 의해 발현이 조절되는 $\mathrm{MMP}$ 중 $\mathrm{MMP}-1$ 은 collagenase 1 으 로 알려져 있으며, type I 와 III collagen을 기질로 한다. MMP-3는 stromelysin 1 이라고도 하며, 기저막의 type IV collagen을 분해하 며 zymogen인 proMMP-1을 활성화시킨다. MMP-9은 gelatinase $\mathrm{B}$ 로 collagenase에 의해 분해된 산물을 더 작게 가수분해한다(Pyun et al., 2012). 자외선에 의하여 MMP-1가 fibillar collagen (types I 와 III)으로 쪼개면서 콜라겐을 분해시키고, 연이어 MMP-3, $\mathrm{MMP}-9$ 를 증가시킨다. 따라서 $\mathrm{MMP}-1$ 과 $\mathrm{MMP}-3$ 의 발현을 억제 함으로써 피부 노화 억제 및 손상된 피부의 재생을 유도하는 주요한 요인이 될 수 있다(Pyun et al., 2012). 본 연구에서는 피부세포 성 

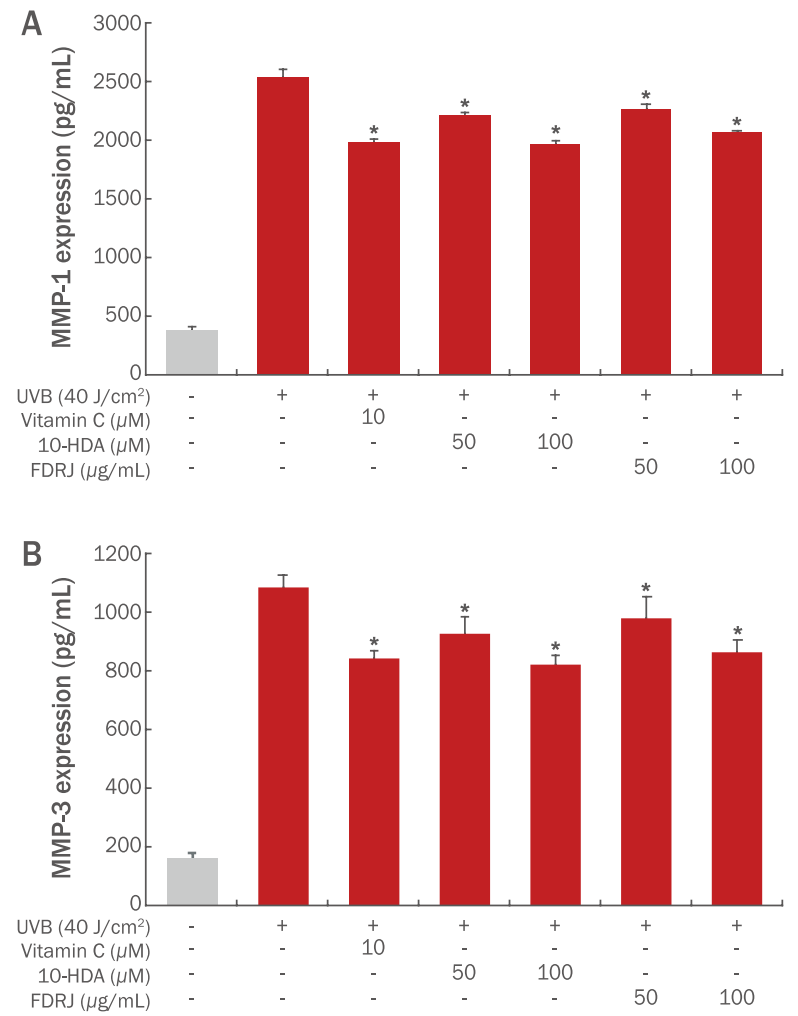

Figure 5. The effects of 10-HDA and freeze-dried royal jelly on MMP-1 and MMP-3 production in UVB-irradiated HaCaT cells.

The production of MMP-1 (A) and MMP-3 (B) were assayed in the culture medium of cells stimulated with UVB $\left(40 \mathrm{~mJ} / \mathrm{cm}^{2}\right)$ for $24 \mathrm{~h}$ in the presence of 10-HDA and freeze- dried royal jelly by ELISA. The data represent the mean $\pm S D$ of triplicate experiments. Vitamin $C$ was used as the positive control. Control was only treated UV-B on the cells. " $p<0.05$ compared with control. FDRJ, freeze-dried royal jelly. MMP-1, -3 , matrix metalloproteinase-1, -3 .

장과 이주에 효과적인 동결건조와 $10-\mathrm{HDA}$ 를 각각 $\mathrm{HaCaT}$ 세포에 다양한 농도별로 처리했을 때의 MMP-1과 MMP-3 효소 발현량 을 ELISA kit를 이용하여 조사하였다. 그 결과 동결건조 로열젤리 와 10- $\mathrm{HDA}$ 를 처리했을 때 $\mathrm{MMP}-1$ 과 $\mathrm{MMP}-3$ 의 발현량이 무 처 리군에 비해 유의하게 감소되는 것으로 확인되었다(Figure 5). 특히 동결건조 로열젤리의 농도 $100 \mu \mathrm{g} / \mathrm{mL}$ 과 $10-\mathrm{HDA}$ 는 농도 $100 \mu \mathrm{M}$ 에서 $\mathrm{MMP}-1$ 과 $\mathrm{MMP}-3$ 의 발현이 가장 크게 억제되는 것으로 확 인되었다.

\section{5. 국산 동결건조 로열젤리와 10-HDA의 $M M P-1$ 및 $M M P-3$ 유}

\section{전자 발현 억제 효과}

동결건조 로열젤리와 10-HDA는 UVB 조사에 의해 발현이 증 가된 $M M P-1$ 과 $M M P-3$ 발현을 대조군 대비 유의한 수준으로 감 소시키는 것으로 확인하였다. 따라서 본 연구에서는 피부 세포 성
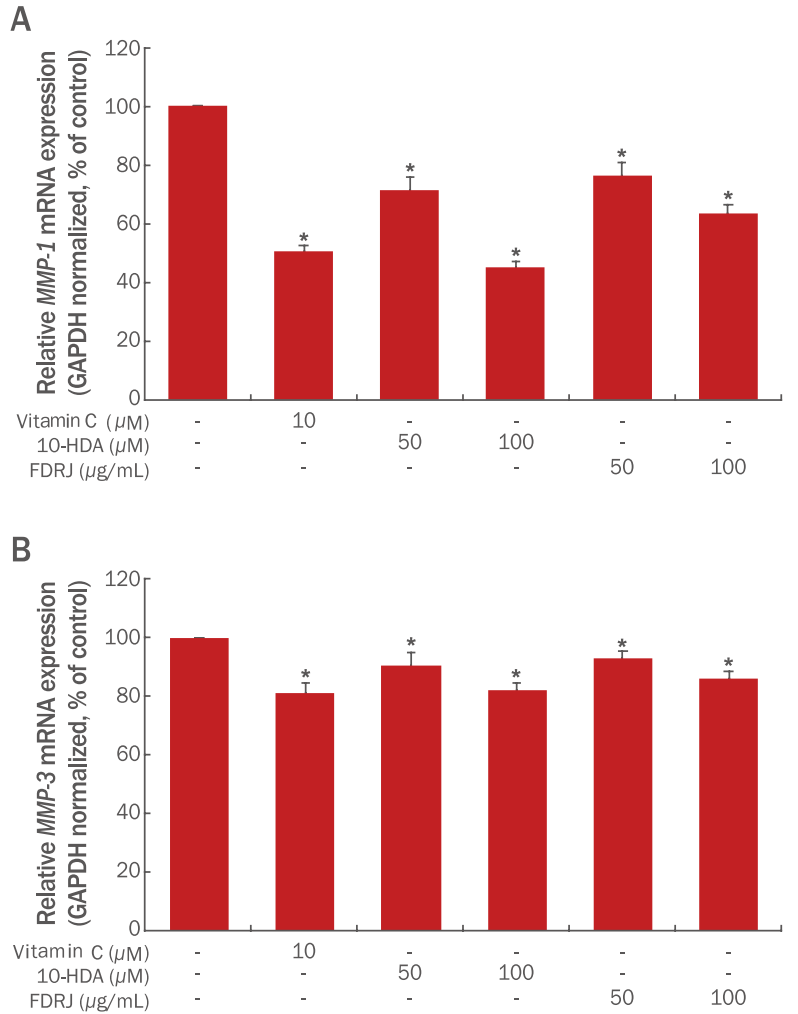

Figure 6. The effects of 10-HDA and freeze-dried royal jelly (FDRJ) on MMP-1 and MMP-3 mRNA levels in UVB-irradiated HaCaT cells.

The cells were pretreated with various concentrations of 10-HDA and freeze dried royal jelly for $1 \mathrm{~h}$ and then irradiated with $40 \mathrm{~mJ} /$ cm UVB. After $24 \mathrm{~h}$ further incubation, mRNA levels of MMP-1 (A) and $M M P-3(B)$ were measured by quantitative real-time PCR. The data represent the mean $\pm S D$ of triplicate experiments. Vitamin $C$ was used as the positive control. Control was only treated UV-B on the cells. ${ }^{*} p<0.05$ compared with control.

장과 이주에 효과적인 동결건조 로열젤리 $100 \mu \mathrm{g} / \mathrm{mL}$ 와 10-HDA $100 \mu \mathrm{M}$ 를 각각 $\mathrm{HaCaT}$ 세포에 처리했을 때의 $M M P-1$ 과 $M M P-3$ 유전자의 발현량을 조사하였다. 그 결과 동결건조 로열젤리와 10$\mathrm{HDA}$ 를 처리했을 때 $\mathrm{UVB}$ 조사에 의해 증가된 $M M P-1$ 과 $M M P-3$ 의 유전자 발현량은 대조군 대비 유의하게 감소 되는 것으로 확인 되었다(Figure 6). 이를 통해 동결건조 로열젤리와 10-HDA는 손 상된 피부의 재생과 이주는 물론 피부 노화 억제에도 효과가 있음 을 확인하였다.

\section{Conclusion}

오래 전부터 로열젤리는 면역 강화, 항노화, 항염, 항산화 작용이 
뛰어나 민간과 한방에서 널리 사용되어 오고 있으나 고시형 기능식 품원료에서 제외되어 국내 로열젤리 시장은 다소 침체되어 있는 상 황이다. 본 연구에서는 실온에서 쉽게 변질되기 쉬운 생로열젤리의 단점을 보완한 국산 동결건조 로열젤리의 효능을 과학적으로 구명 하고 기능성식품 소재로의 활용하기 위한 기능성 지표 성분을 탐색 하고자 하였다. 국산 동결건조 로열젤리는 단백질과 탄수화물, 지질 은 각각 $38.8 \pm 3.6,37.4 \pm 5.52,7.0 \pm 1.74 \%$ 을 함유하고 $10-\mathrm{HDA}$ $6.2 \pm 0.69 \%$ 등 주요 성분을 함유하였다. 동결건조 로열젤리는 각질 형성세포인 $\mathrm{HaCaT}$ 세포의 wound healing 모델을 이용한 동결건조 로열젤리와 10- $\mathrm{HDA}$ 의 피부 재생 및 이주 효능을 측정한 결과 각각 $100 \mu \mathrm{g} / \mathrm{mL}, 100 \mu \mathrm{M}$ 의 농도에서 피부 재생과 이주 효율이 유의적 으로 증가하는 것으로 관찰되었다. 뿐만 아니라 동결건조 로열젤리 와 10-HDA는 자외선에 의해 유도된 피부세포 노화의 원인인 콜라 겐 감소에 관여하는 $\mathrm{MMP}-1$ 과 $\mathrm{MMP}-3$ 생성 및 $\mathrm{mRNA}$ 발현을 효 과적으로 억제하는 것으로 분석되었다. 따라서 본 연구결과를 통해 국산 동결건조 로열젤리는 피부 주름 개선용 천연물질 건강기능식 품 원료로서 활용 가능성이 높으며 이러한 효능은 로열젤리의 주요 성분인 $10-\mathrm{HDA}$ 에서도 동일한 효능을 갖는 것으로 확인되었다.

\section{Acknowledgements}

본 연구는 농촌진흥청 농업기초기반연구 어젠다연구사업(과제 번호: PJ01513501)에 의하여 수행된 것으로 이에 감사드립니다.

\section{Author's contribution}

HYK performed cellular experiments and analyzed the data. HMC and SEK performed biochemical experiments and analyzed the data. HJM performed the preparation of the experiment materials. SMH designed project and wrote the manuscript.

\section{Author details}

Hyo Young Kim (Post-Doc, Researcher), Department of Agricultural Biology, National Institute of Agricultural Sciences, Wanju-gun, Jellabuk-do 55365, Korea; Hong Min Choi (Research Assistant), Department of Agricultural Biology, National Institute of Agricultural Sciences, Wanjugun, Jellabuk-do 55365, Korea; Se Gun Kim (Researcher), Department of Agricultural Biology, National Institute of Agricultural Sciences, Wanju-gun, Jellabuk-do 55365, Korea; Soon Ok Woo (Senior Researcher), Department of Agricultural Biology, National Institute of Agricultural Sciences, Wanju-gun, Jellabuk-do 55365, Korea; Hyo Jung Moon (Research Assistant), Department of Agricultural
Biology, National Institute of Agricultural Sciences, Wanjugun, Jellabuk-do 55365, Korea; Sang Mi Han (Senior Researcher), Department of Agricultural Biology, National Institute of Agricultural Sciences, Wanju-gun, Jellabuk-do 55365, Korea.

\section{References}

Brennan M, Bhatti H, Nerusu KC, Bhagavathula N, Kang S, Fisher GJ, Varani J, Voorhees JJ. Matrix metalloproteinase-1 is the major collagenolytic enzyme responsible for collagen damage in UV-irradiated human skin. Photochemistry and Photobiology, 78: 43-48, 2003.

Choung MG, Hwang YS, Kim GP, Ahn GK, Shim HS, Hong SB, Choi JH, Yu CY, Chung IM, Kim SH, et al. Antimelanogenic effect and whitening of anthocyanin rich fraction from seeds of Liriope platyphylla. Korean Journal of Medicinal Crop Science, 21: 361-371, 2013.

Fisher GJ, Wang ZQ, Datta SC, Varani J, Kang S, Voorhees JJ. Pathophysiology of premature skin aging induced by ultraviolet light. The New England Journal of Medicine, 337: 1419-1428, 1997.

Fujiwara S, Imai J, Fujiwara M, Yaeshima T, Kawashima T, Kobayashi K. A potent antibacterial protein in royal jelly. Purification and determination of the primary structure of royalisin. The Journal of Biological Chemisty, 265: 11333-11337, 1990.

Han SM, Yeo JH, Cho YH, Pak SC. Royal jelly reduces melanin synthesis through down-regulation of tyrosinase expression. The American Journal of Chinese Medicine. 39: 1253-1260. 2011.

Kalbina I, Strid Å. Supplementary ultraviolet-B irradiation reveals differences in stress responses between Arabidopsis thaliana ecotypes. Plant, Cell \& Environment, 29: 754-763, 2006.

Kim SG, Jung HJ, Yeo JH, Hong IP, Woo SO, Jang HR, Han SM. New Analytical method for 10-HDA in royal jelly using UHPLC. Journal of Apiculture, 29: 313-317. 2014.

Kim J, Park JG, Lee CM, Kim SG. Effect of the pine cone extract phytochemical and physiological activity on HaCaT cells. Asian Journal of Beauty and Cosmetology, 17: 353-363, 2019. 
Lee J, Park S. Review of the usability of cyclodextrin as a cosmetic ingredient. Asian Journal of Beauty and Cosmetology, 17: 545-553. 2019.

Lin Y, Shao Q, Zhang M, Lu C, Fleming J, Su S. Royal jellyderived proteins enhance proliferation and migration of human epidermal keratinocytes in an in vitro scratch wound model. BMC Complementary and Alternative Medicine. 19: 175, 2019.

Ma J, Luo XD, Protiva P, Yang H, Ma C, Basile MJ, Weinstein IB, Kennelly EJ. Bioactive novel polyphenols from the fruit of Manilkara zapota (Sapodilla). Journal of Natural Products, 66: 983-986, 2003.

Ministry of Food and Drug Safety (KFDA). Regulations concerning recognition of functional ingredients and standards: skin health. Ministry of Food and Drug Safety, Osong, pp1-18, 2019a.

Ministry of Food and Drug Safety (KFDA). Food regulation: Chapter 5 standards and specifications for food, Ministry of Food and Drug Safety, Osong, pp571-572, 2019b.

Ministry of Food and Drug Safety (KFDA). Food regulations: Chapter 8 general test methods. Ministry of Food and Drug Safety, Osong, pp1-316, 2019c.

Nagai T, Inoue R. Preparation and the functional properties of water extract and alkaline extract of royal jelly. Food Chemistry, 84: 181-186, 2004.

Pyun HB, Kim M, Park J, Sakai Y, Numata N, Shin JY, Shin HJ, Kim DU, Hwang JK. Effects of collagen tripeptide supplement on photoaging and epidermal skin barrier in UVB-exposed hairless mice. Preventive Nutrition and Food Science, 17: 245-253, 2012.

Quan T, Fisher GJ. Role of age-associated alterations of the dermal extracellular matrix microenvironment in human skin aging. Gerontology, 61: 427-434, 2015.

Rittié L, Fisher GJ. UV-light-induced signal cascades and skin aging. Ageing Research Reviews, 1: 705-720, 2002.

Ryu JY, Rhie SJ, Lim KH, Choi YE, Han HS, Yang HO, Na EJ. Inhibitory effects of prunin on photo-aging in human keratinocytes (HaCaT) damaged by UVB radiation. Asian Journal of Beauty and Cosmetology, 17: 139-147, 2019.

Scharffetter-Kochanek K, Brenneisen P, Wenk J, Herrmann G, Ma W, Kuhr L, Meewes C, Wlaschek M. Photoaging of the skin from phenotype to mechanisms. Experimental Gerontology, 35: 307-316, 2000.

Varani J, Warner RL, Gharaee-Kermani M, Phan SH, Kang S, Chung JH, Wang ZQ, Datta SC, Fisher GJ, Voorhees JJ. Vitamin a antagonizes decreased cell growth and elevated collagen-degrading matrix metalloproteinases and stimulates collagen accumulation in naturally aged human skin. Journal of Investigative Dermatology, 114: 480-486, 2000.

Zhang S, Duan E. Fighting against skin aging: the way from bench to bedside. Cell Transplantation, 27: 729-738, 2018. 


\section{국문초록}

\section{인간 각질형성세포에서 국산 동결건조 로열젤리의 피부 건강 개선 효과}

김효영, 최홍민, 김세건, 우순옥, 문효정, 한상미

국립농업과학원 잠사양봉소재과, 전라북도 완주군, 한국

목적: 본 연구는 국산 로열젤리의 피부건강에 도움을 주는 건강기능식품 원료로 개발하기 위하여 동결건조 로열젤리와 주요성분인 10-Hydroxydecanoic acid (10-HDA) 피부 노화 억제효과를 확인하고자 하였다. 방법: 인간 각질형성세포(HaCaT)를 대상으로 국 산 동결건조 로열젤리와 10-HDA 처리에 따른 피부 상처 모델에서의 세포 증식 및 이주 효능을 EZ-cytox kit assay를 이용하여 분 석하였다. 또한 자외선 $\mathrm{B}$ 를 조사 후 $\mathrm{HaCaT}$ 세포에서 피부 노화에 관련된 matrix metalloproteinase $(M M P)-1$ 과 $M M P-3$ 의 생성 량 변화는 enzyme-linked immunosorbent assay로 확인하였고 유전자 발현은 real-time polymerase chain reaction으로 분석하였 다. 결과: 국산 동결건조 로열젤리와 10- $\mathrm{HDA}$ 는 기계적으로 손상된 $\mathrm{HaCaT}$ 세포의 재생 촉진과 및 이주 능력을 향상시켰으며 특히 동결건조 로열젤리 $100 \mu \mathrm{g} / \mathrm{mL}$ 및 10- $\mathrm{HDA} 100 \mu \mathrm{M}$ 의 농도로 처리한 시험군은 양성 대조군으로 사용한 vitamin C와 유사한 것으 로 확인되었다. 또한 자외선 $\mathrm{B}$ 로 인해 손상된 $\mathrm{HaCaT}$ 세포에서 콜라겐 생성을 억제하여 피부노화를 유발하는 $M M P-1$ 과 $M M P-3$ 생성 및 유전자 발현량을 유의적으로 감소시켰다. 결론: 본 연구 결과를 통하여 국산 동결건조 로열젤리와 로열젤리의 주요 성분인 10-HDA의 피부 주름 생성을 억제 효능을 확인하였으며 피부 건강 기능성식품 원료로서 가능성을 제시하였다.

핵심어: 로열젤리, 10-HDA, 건강기능식품, 인간 각질형성세포, 항주름

본 연구는 2020년도 농촌진흥청 어젠다연구사업(과제번호: PJ01513501)에 의해 수행됨.

\section{참고문헌}

김세건, 정현주, 여주홍, 홍인표, 우순옥, 장혜리, 한상미. UHPLC를 이용한 로얄제리의 $10-\mathrm{HDA}$ 분석법 개발. Journal of Apiculture, 29: 313-317, 2014.

김진, 박징기, 이창문, 김수관. 솔방울 추출물의 파이토케미컬 성분 평가 및 $\mathrm{HaCaT}$ 세포이동 평가. 아시안뷰티화장품학술 지, 17: 353-363, 2019.

류지영, 이승자, 임계화, 최영은, 한효선, 양현옥, 나은주. Prunin의 자외선 B에 의해 손상된 인간 각질형성세포 (HaCaT) 에 대한 광노화 억제 효과. 아시안뷰티화장품학술지, 17: 139-147, 2019.

식품의약품안전처. 건강기능식품 기능성 평가 가이드: 피부건강에 도움을 줄 수 있음, 식품의약품안전처, 오송, $\mathrm{pp} 1-18$, 2019a.

식품의약품안전처. 식품공전: 제 5. 식품별 기준 및 규격. 식품의약품안전처, 오송, pp571-572, 2019b.

식품의약품안전처. 식품공전: 제 8. 일반시험법. 식품의약품안전처, 오송, pp1-316, 315-316, 2019c.

이재은, 박세연. 사이클로덱스트린(Cyclodextrin)의 화장품 유효성분으로서의 유용성 고찰. 아시안뷰티화장품학술지, 17: 545-553, 2019.

정명근, 황영선, 김기쁨, 안경근, 심훈섭, 홍승범, 최재후, 유창연, 정일민, 김승현, et al. 맥문동 종실 안토시아닌 분획물 의 멜라닌 생성 억제 및 미백 효과. 한국약용작물학회지, 21: 361-371, 2013. 


\section{中文摘要}

\section{韩国冻干蜂王浆对人角质形成细胞的皮肤健康改善作用}

金孝榮，崔洪珉，金世建，禹順玉，文孝貞，韓相美

国立农业科学院农业生物学系，全罗北道完州郡，韩国

目的: 研究韩国冻干蜂王浆及其主要成分10-HDA的抗皮肤衰老作用, 以促进韩国蜂王浆成为健康功能食品改善 皮肤健康的成分。方法: 使用EZ-cytox试剂盒检测皮肤伤口愈合模型中人角质形成细胞（HaCaT细胞）的增殖和 迁移，从而确定韩国冻干蜂王浆和10-HDA的作用。使用酶联免疫吸附试验分析了UV-B照射后, HaCaT细胞中 皮肤老化与基质金属蛋白酶 (MMP)- 1 和 $M M P-3$ 产生的变化。实时聚合酶链反应用于分析 $M M P-1$ 和 $M M P-3$ 基因表 达。结果: 韩国冻干蜂王浆和 $10-H D A$ 改善了机械损伤的 $\mathrm{HaCaT}$ 细胞的再生和迁移。用 $100 \mu \mathrm{g} / \mathrm{mL}$ 的韩国冻干蜂 王浆和100 $\mu \mathrm{M}$ 的10-HDA处理的测试组与用维生素C处理的阳性对照组所获得的结果相似。此外, 韩国的冻干蜂 王浆和10-HDA 显着降低了MMP-1和MMP-3的产生和基因表达, MMP-1和MMP-3是通过抑制UVB照射的HaCaT 细胞中的胶原蛋白生成来诱导皮肤衰老的关键元素。结论：通过研究确认了韩国冻干蜂王浆及其主要成分 10HDA的抗皱作用，作为改善皮肤健康的关键功能性保健食品原料的可行性。

关键词: 蜂王浆，10-羟基癸酸，保健食品，人角质形成细胞，抗皱 